\title{
Effects of melatonin administration on embryo implantation and offspring growth in mice under different schedules of photoperiodic exposure
}

\author{
Lu Zhang ${ }^{1,2+}$, Zhenzhen Zhang ${ }^{1 \dagger}$, Feng Wang ${ }^{1}$, Xiuzhi Tian ${ }^{1}$, Pengyun $\mathrm{Ji}^{1}$ and Guoshi Liu ${ }^{1 *}$
}

\begin{abstract}
Background: Embryo implantation is crucial for animal reproduction. Unsuccessful embryo implantation leads to pregnancy failure, especially in human-assisted conception. Environmental factors have a profound impact on embryo implantation. Because people are being exposed to more light at night, the influence of long-term light exposure on embryo implantation should be explored.
\end{abstract}

Methods: The effects of long photoperiodic exposure and melatonin on embryo implantation and offspring growth were examined. Long photoperiodic exposure (18:6 h light:dark) was selected to resemble light pollution. Melatonin $\left(10^{-2}, 10^{-3}, 10^{-4}, 10^{-5} \mathrm{M}\right)$ was added to the drinking water of mice starting at Day 1 (vaginal plugs) until delivery.

Results: Melatonin treatment $\left(10^{-4}, 10^{-5} \mathrm{M}\right)$ significantly increased litter sizes compared to untreated controls $(12.9 \pm 0$. 40 and $12.2 \pm 1.01$ vs. $11.5 \pm 0.43 ; P<0.05)$. The most effective concentration of melatonin $\left(10^{-4} \mathrm{M}\right)$ was selected for further investigation. No remarkable differences were found between melatonin-treated mice and controls in terms of the pups' birth weights, weaning survival rates, and weaning weights. Long photoperiodic exposure significantly reduced the number of implantation sites in treated mice compared to controls (light/dark, 12/12 h), and melatonin rescued this negative effect. Mechanistic studies revealed that melatonin enhanced the serum 17ß-estradiol $\left(E_{2}\right)$ levels in the pregnant mice and upregulated the expression of the receptors MT1 and MT2 and p53 in uterine tissue. All of these factors may contribute to the beneficial effects of melatonin on embryo implantation in mice.

Conclusion: Melatonin treatment was associated with beneficial effects in pregnant mice, especially those subjected to long photoperiodic exposure. This was achieved by enhanced embryo implantation. At the molecular level, melatonin administration probably increases the $E_{2}$ level during pregnancy and upregulates p53 expression by activating MT1/2 in the uterus. All of the changes may improve the microenvironment of the uterus and, thus, the outcomes of pregnancy.

Keywords: Melatonin, Embryo implantation, MT1, MT2, p53

\footnotetext{
* Correspondence: gshliu@cau.edu.cn

${ }^{\dagger}$ Equal contributors

${ }^{1}$ State Key Laboratory of Animal Nutrition, Key Laboratory of Animal Genetics and Breeding of the Ministry of Agriculture, National Engineering Laboratory for Animal Breeding, College of Animal Science and Technology, China Agricultural University, Beijing 100193, China

Full list of author information is available at the end of the article
} 


\section{Background}

Implantation is a crucial process that involves an intricate interaction between the embryo and uterus. The defects that occur before, during or immediately after implantation are responsible for early pregnancy loss in animals, including humans. For successful implantation, an embryo needs to be developed to the blastocyst phase and the uterus must be in a receptive state, which allows the blastocyst to communicate with the luminal epithelium [1]. Similar to other physiological processes, implantation is regulated by various factors, including hormones, cytokines, associated gene expression and protein synthesis $[1,2]$. Progesterone $\left(\mathrm{P}_{4}\right)$ and $\mathrm{E}_{2}$ are master regulators of implantation in both mice and humans because $\mathrm{P}_{4}$ and $\mathrm{E}_{2}$ modify the receptive status of the uterus and promote embryo implantation [3-5]. In mice, $\mathrm{E}_{2}$ and $\mathrm{P}_{4}$ perform their functions via their receptors, and mice that lack estrogen receptors $(E R \alpha)$ or progesterone receptor (PR-A) are infertile [6-8]. In addition, leukaemia inhibitory factor (LIF) and p53 are key factors for embryo implantation [9]. LIF acts as a downstream target for estrogen and is involved in the decidualization of the maternal endometrium for blastocyst implantation [9-11]. Additionally, p53 regulates both the basal and inducible transcription of LIF to regulate the process of implantation $[9,12,13]$.

Melatonin may have a potent impact on embryo implantation. As an amphiphilic molecule, melatonin enters the cell with ease to exert its biological functions, including the regulation of the biological clock and immune responses, the detoxification of free radicals and the modification of hormone and growth factor secretion [14-17]. Melatonin also plays an important role in reproductive activities by affecting the secretion of gonadotropin in the hypothalamus via the hypothalamus-pituitary-gonads (HPG) axis to regulate sexual maturation, seasonal oestrus, reproductive behaviour, redox homeostasis and gamete protection [17, 18]. Melatonin exerts some of its functions via its receptors, whereas others are independent of receptors [19]. The differential expression of the melatonin receptors MT1 and MT2 in pregnant and non-pregnant human uteri has been reported and influences a 24-h rhythm of myometrial contractility [20]. Melatonin receptors also exist in human granulosa cells (GCs), and melatonin treatment was shown to enhance the effects of human chorionic gonadotropin-stimulated progesterone production in vitro [21-23]. In addition, melatonin treatment in the range of $10 \mathrm{pM}-100 \mathrm{nM}$ significantly upregulated the gene expression of the $\mathrm{LH}$ receptor [23]. The effects of melatonin on $\mathrm{P}_{4}$ and $\mathrm{E}_{2}$ production are rather complicated. For example, in growing and luteinized GCs, short-term melatonin incubation (within $48 \mathrm{~h}$ ) results in reduced $\mathrm{P}$ secretion; however, long-term incubation increases $\mathrm{P}_{4}$ production [22, 23]. In pinealectomized rats, the embryo implantation rates and serum $\mathrm{P}_{4}$ levels are decreased, but with daily melatonin injection, the serum $\mathrm{P}_{4}$ levels are normalized [24, 25]. In pinealectomized rats, low melatonin levels lead to a reduction in $\mathrm{P}_{4}$ and its receptors but result in an elevation in $\mathrm{E}_{2}$ levels [26]. In the uteri of non-pregnant pinealectomized rats, melatonin increases the progesterone receptor (PR) levels but reduces $\mathrm{E}_{2}$ receptor (ER) expression [27]. In another study, melatonin significantly reduces $\mathrm{LH}$ and $17 \beta$ estradiol levels in plasma and downregulates the expression of ER $\beta$ and PR $\beta$; however, it upregulates MT1 expression [28]. Melatonin might also decrease the $\mathrm{E}_{2}$ levels during the perimenopausal period [29].

The beneficial effects of melatonin on embryo implantation have been reported in mice and can be attributed to the regulation of hormone secretion and hormone receptor activation [30, 31]. In addition, melatonin can modulate the activity of p53 by inducing the p38-dependent phosphorylation of p53 in MCF-7 cells [32]. The activation of p53-dependent DNA damage response is mediated by MT1 and MT2 in mice [33]. These actions of melatonin could also positively affect embryo implantation. Recently, it was reported that the expression of the enzyme $A A N A T$, which catalyses the synthesis of melatonin, is gradually increased during early gestation and that melatonin injection increase the number of embryo implantation sites and upregulates the expression of ErbB1 and $p 53$ [34].

However, it is unclear whether melatonin has other effects on offspring development and growth, particularly in animals that are subjected to long photoperiodic exposure and have truncated melatonin production with circadian disturbances. This is specifically important for modern humans $[35,36]$, who are being exposed to more manufactured light at night [37]. The reproductive consequences of long photoperiodic exposure in mice or humans have not yet been explored. Therefore, in the current study, we evaluated litter size, birth weight, weaning survival rates and weaning weight after melatonin treatment. We also detected the number of implantation sites in the uteri of mice that were either treated with melatonin or subjected to long photoperiodic exposure. The potential signalling pathway of melatonin in the regulation of embryo implantation was also investigated by determining the protein levels of melatonin receptors, p53 and LIF.

\section{Methods}

\section{Chemicals}

$\mathrm{E}_{2}$ and $\mathrm{P}_{4}$ hormone radioactive assay kits were purchased from ICN (ICN Biomedicals, Inc., Costa Mesa, CA, USA), the PVDF membrane and ECL were from 
Luminex xMAP - EMD Millipore (MA, USA), goat antirabbit IgG $(\mathrm{H}+\mathrm{L})$, goat anti-mouse IgG $(\mathrm{H}+\mathrm{L})$, HRP and rabbit anti-goat IgG $(\mathrm{H}+\mathrm{L})$ were from Jackson Immunoresearch Laboratories (PA, USA); protein extraction RIPA was from Thermo Fisher Scientific (MA, USA); the MT1 antibody (SC-390328; Santa Cruz Bio Inc., Santa Cruz, CA, USA), MT2 antibody (SC-13177; Santa Cruz Bio Inc.) and p53 antibody (SC-47698; Santa Cruz Bio Inc.) were from Santa Cruz Biotechnology; the protein marker was from Thermo Fisher Scientific; and the separation gel buffer, stacking gel buffer, 20\% Tween 20 and protein sample buffer were from Bio-Rad Lab (CA, USA). Melatonin and other reagents, unless specified, were purchased from Sigma Chemical Co. (MO, USA).

\section{Animals}

Kun Ming (KM) mice (China Experimental Animal Center of Military Medical Sciences, Beijing, China) aged 8-12 weeks were kept in a temperature-controlled room at $20 \sim 22{ }^{\circ} \mathrm{C}$ under a 12:12 light/dark cycle (lights on at 06:00 and off at 18:00). After a week of acclimation, spontaneous oestrus female mice were carefully selected and kept with sexually mature males overnight. On the following morning, females were checked for vaginal plugs. Those with vaginal plugs were selected for the subsequent experiments.

\section{Implantation site quantification}

On days 5.5 and 7.5 of pregnancy, mice received a peritoneal injection of $2 \%$ pentobarbital sodium $(0.15 \mathrm{ml} /$ each) and were then injected with Chicago Sky Blue 6B via the caudal vein $(0.10 \mathrm{ml} / \mathrm{each})$. Three minutes later, mice were sacrificed by cervical dislocation. The uteri were collected, cleaned and placed on white paper. The implantation sites were counted and recorded.

\section{$17 \beta$-estradiol and progesterone assays}

The levels of $\mathrm{P}$ and $\mathrm{E}_{2}$ were detected by radioimmunoassays (RIAs). On days 4 and 4.5 of pregnancy, mice received a peritoneal injection of $2 \%$ pentobarbital sodium $(0.15 \mathrm{ml} /$ each $)$, and the blood was collected and stored at $4^{\circ} \mathrm{C}$ for $2 \mathrm{~h}$ and centrifuged for $10 \mathrm{~min}$ at $3000 \mathrm{r} / \mathrm{min}$. The serum was collected and stored at $-80^{\circ} \mathrm{C}$ for future $\mathrm{E}_{2}$ and $\mathrm{P}$ detection according to the kit's instructions.

\section{Western blotting}

Uteri from 4.5 day pregnant mice were collected and washed three times with PVA-DPBS, lysed in sample buffer containing $62.5 \mathrm{mM}$ Tris- $\mathrm{HCl}(\mathrm{pH} 6.7), 5 \% 2-$ mercaptoethanol, $2 \%$ sodium dodecyl sulfate, $10 \%$ glycerol, and $0.002 \%$ bromophenol blue, denatured by heating to $100{ }^{\circ} \mathrm{C}$ for $5 \mathrm{~min}$ and frozen at $-80^{\circ} \mathrm{C}$ until use. The proteins were subjected to SDS-PAGE using a $10 \%$ polyacrylamide gel and then transferred to a PVDF membrane for $2.5 \mathrm{~h}$ under a $300-\mathrm{mA}$ electric current. After blocking the nonspecific binding sites by overnight incubation in Tris-buffered saline $(25 \mathrm{mM}$ Tris and $150 \mathrm{mM} \mathrm{NaCl}, \mathrm{pH} 7.6$ ) containing 5\% nonfat milk and $0.2 \%$ Tween 20 , the membranes were incubated with the primary antibodies (dilution 1: 1000) for $2 \mathrm{~h}$ at $37{ }^{\circ} \mathrm{C}$. The membranes were stripped with a buffer containing $100 \mathrm{mM}$ 2-mercaptoethanol, 2\% SDS, and $62.5 \mathrm{mM}$ Tris- $\mathrm{HCl}(\mathrm{pH} 6.7)$, then re-probed with a mouse monoclonal antibody (dilution 1:1000) directed against $\beta$-actin (Ab6276; Abcam, Inc., Burlingame, CA, USA) to confirm equivalent protein loading. The bound antibodies were detected by incubation with a secondary antibody (dilution 1:1000) (Peroxidase AffiniPure Rabbit Anti-Goat IgG $(\mathrm{H}+\mathrm{L}))$. The images were scanned in an Image Quant LAS 4000 mini luminescent image analyser (GE Healthcare Bio-Sciences, PA, USA). The protein levels were evaluated by densitometry using the Quantity One software (v. 4.52; Bio-Rad Lab).

\section{Experimental designs Experiment I}

Females with vaginal plugs (the initiation of pregnancy, day 1) were divided into five groups (10/group) and treated with different concentrations of melatonin $\left(10^{-2}\right.$, $10^{-3}, 10^{-4}, 10^{-5}$ and $0 \mathrm{M}$ ) in their drinking water. The water was replaced every day until delivery. After delivery, the litter size, litter weight, average pup birth weight, weaning body weight and postnatal survival rate were recorded.

\section{Experiment II}

Mice with vaginal plugs were divided into four groups: mice without treatment served as a control group; mice treated with melatonin $\left(10^{-4} \mathrm{M}\right)$ comprised the MT group; mice exposed to a long photoperiod $(18 \mathrm{~h} / 6 \mathrm{~h}$ light/dark) constituted the LE group; mice exposed to a long photoperiod $(18 \mathrm{~h} / 6 \mathrm{~h}$ light/dark) plus melatonin $\left(10^{-4} \mathrm{M}\right)$ treatment were placed in the LE + MT group. On Days 5.5 and 7.5 of pregnancy, mice were sacrificed and their uteri were collected for implantation site analysis.

\section{Experiment III}

Mice with vaginal plugs were selected and treated with or without melatonin $\left(10^{-4} \mathrm{M}\right)$ under the same management condition. On Days 4 and 4.5, blood was collected for the detection of serum $\mathrm{E}_{2}$ and $\mathrm{P}_{4}$ following the instructions of the assay kits. On Day 4.5, uteri were also collected to analyse the protein levels of MT1, MT2, p53 and LIF via western blotting. 


\section{Statistical analyses}

All data were expressed as the mean \pm S.E.M. ANOVA was used to analyse the normality of the data, followed by Dunnett's post hoc test to determine the significant differences between the groups using the SPSS 18.0 statistical software (SPSS Inc., IL, USA). The significance level was set as $P<0.05$.

\section{Results}

\section{Experiment I: Effects of melatonin on pregnant mice}

The average litter sizes in melatonin $10^{-4} \mathrm{M}$ and $10^{-5} \mathrm{M}$ treated groups were significantly greater than those in the control group $(12.9 \pm 0.40$ and $12.2 \pm 1.01$ vs. $11.5 \pm 0.43$; Fig. 1a; $\mathrm{P}<0.05)$. This index was not significantly different between mice treated with melatonin at $10^{-3} \mathrm{M}(12.00 \pm 0.92$; Fig. 1a) and control mice (P 0.05). Melatonin treatment at the concentration of $10^{-2} \mathrm{M}(10.97 \pm 1.453)$ slightly decreased the average litter sizes of mice; however, this decrease was not significantly compared to controls $(P>0.05)$. The results indicated that the most effective melatonin concentration for litter size increase is $10^{-4} \mathrm{M}$. Thus, this concentration was selected for further studies. The survival rate of pups at the time of weaning in the melatonin-treated group slightly increased compared to the control group; however, this increase was not significantly different $(95.6 \pm 1.78 \%$ vs. $92.9 \pm 2.62 \%$; Fig. $1 b ; P>0.05)$. The average litter weight at birth in melatonin $\left(10^{-4} \mathrm{M}\right)$ treated mice was significantly greater than control $(23.2 \pm 0.65$ g vs. $20.9 \pm 0.72$ g; Fig. 1c; $P>$ $0.05)$.The pups' birth weights and 3rd week weaning weights were similar between the $10^{-4} \mathrm{M}$ melatonin and control group $(1.8 \pm 0.20 \mathrm{~g}$ vs. $1.8 \pm 0.17 \mathrm{~g} ; 11.5 \pm 0.43 \mathrm{~g}$ vs. $12.0 \pm 0.41$ g; Fig. 1 d; $P>0.05$ ).

\section{Experiment II: Effects of melatonin on embryo implantation sites on day 5.5 and 7.5 of pregnancy under different photoperiod period}

The implantation sites analysis showed that there was no significant difference between the control and melatonin-treated groups at Day 5.5 of pregnancy $(14.8 \pm 0.62$ vs. $14.0 \pm 0.67$; Fig. 2 a; $P>0.05)$. The numbers of implantation sites in the LE group $(11.2 \pm 0.43)$ was significantly lower compared to controls $(14.8 \pm 0.62)$ and this decrease almost recovered to the

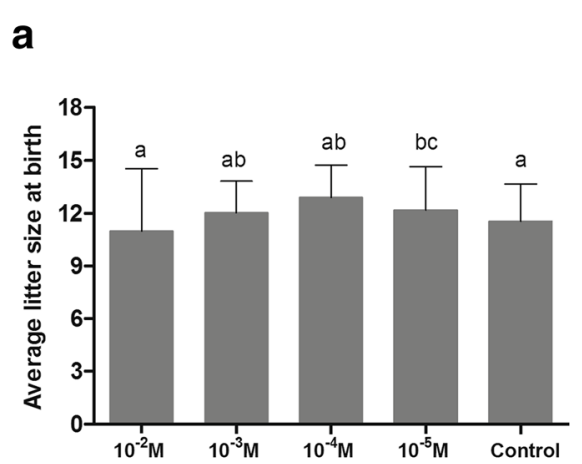

C

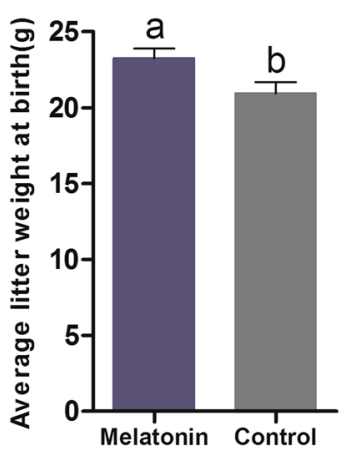

d
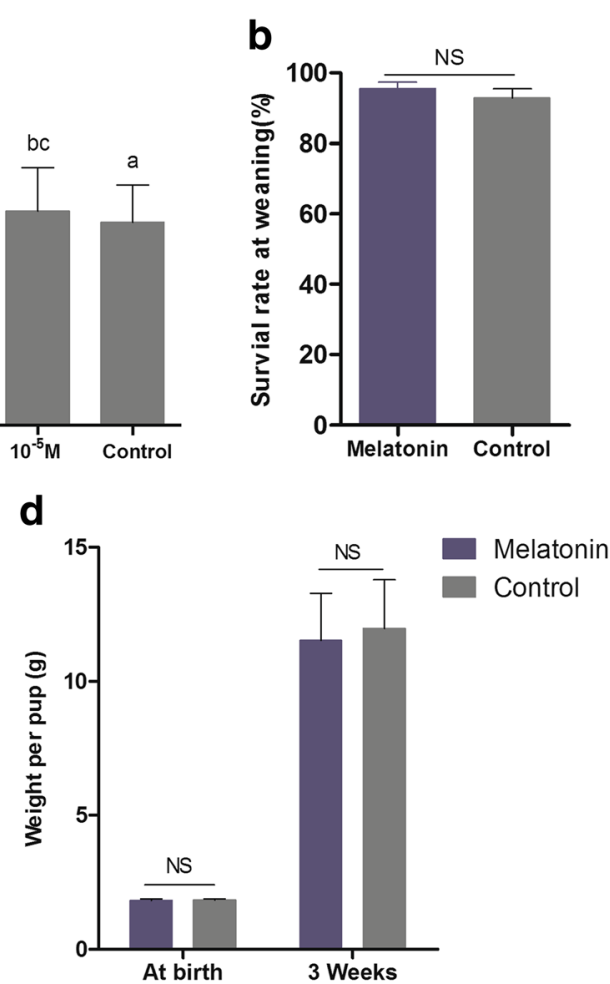

Fig. 1 Effects of different concentrations of melatonin on offspring development and growth in mice. a The average litter sizes for $10^{-2}, 10^{-3}, 10^{-4}$ and $10^{-5} \mathrm{M}$ melatonin-treated groups and the control group $(10.97 \pm 1.453,12.00 \pm 0.92,12.9 \pm 0.40$ and $12.2 \pm 1.01$ vs. $11.5 \pm 0.43$, respectively). b The survival rates of pups at weaning in the melatonin $\left(10^{-4} \mathrm{M}\right)$ and control group $\left(95.6 \pm 1.78 \%\right.$ vs. control $92.9 \pm 2.62 \%$, respectively; $\left.P^{>} 0.05\right)$. c The average litter weight at birth in the melatonin $\left(10^{-4} \mathrm{M}\right)$ and control group $(23.24 \pm 0.65 \mathrm{vs}$. control $20.95 \pm 0.72$, respectively; $P<0.05)$. d The birth weight and 3 rd week weaning weight per pup in the melatonin treated group $\left(10^{-4} \mathrm{M}\right)$ and the control group $(1.8 \pm 0.20 \mathrm{~g}$ vs. control $1.8 \pm 0.17 \mathrm{~g}$; $11.5 \pm 0.43 \mathrm{~g}$ vs. control $12.0 \pm 0.41 \mathrm{~g}$, respectively; $P>0.05)$. Data are expressed as the means $\pm S E M(N=10$ litters/group). Different superscript letters indicate statistically significant differences $(P<0.05)$ 

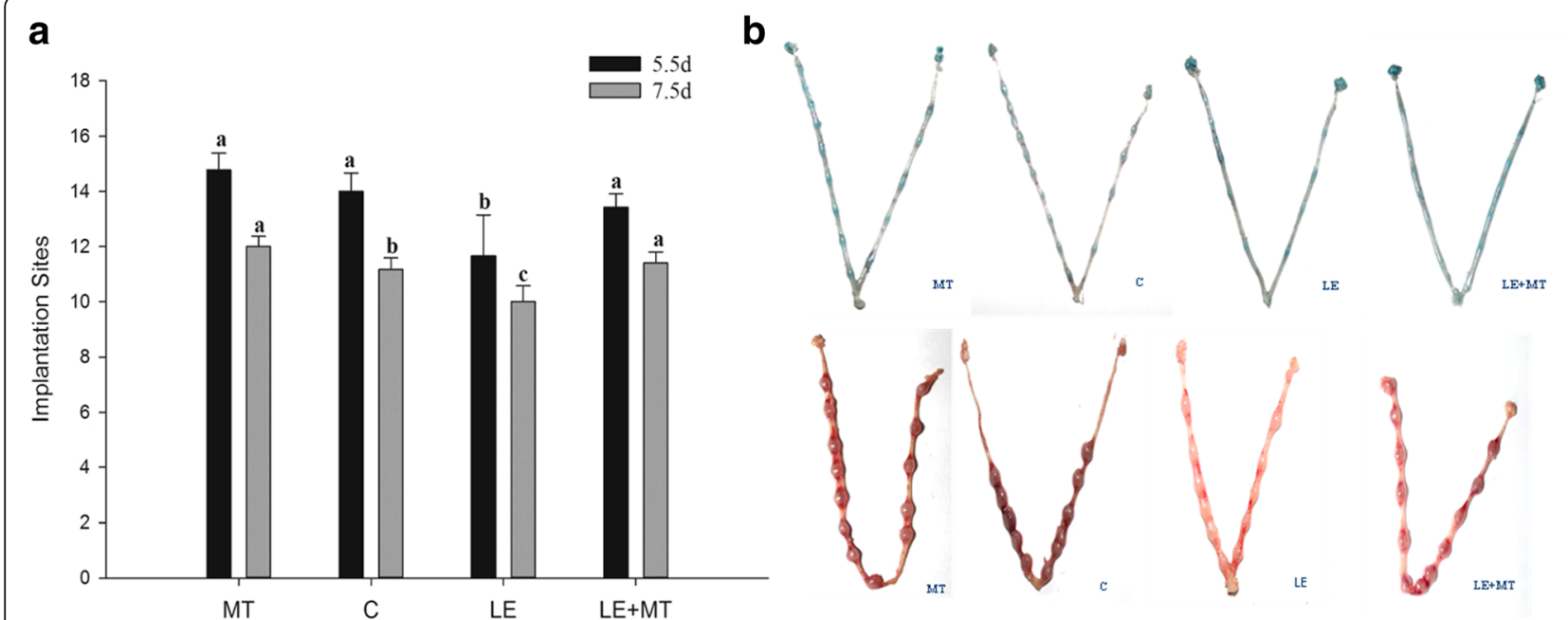

Fig. 2 The implantation sites on Days 5.5 and 7.5 of pregnancy. MT: melatonin group; C: control group; LE: light extended group; LE + MT: light extended group treated with melatonin $\left(10^{-4} \mathrm{M}\right)$. a Implantation sites on Day 5.5 $(14.8 \pm 0.62,14.0 \pm 0.67,11.2 \pm 0.43$ and $13.4 \pm 0.48$ in the MT, C, LE and LE + MT groups, respectively) and on Day $7.5(12.0 \pm 0.37,11.7 \pm 1.48,10.0 \pm 0.58$ and $11.4 \pm 0.40$ in the MT, C, LE and LE + MT groups, respectively). b Representative images of uterine implantation sites on Day 5.5 (up) and Day 7.5 (down) of pregnancy. Data are expressed as the means $\pm \operatorname{SEM}(N=9)$. Different superscript letters indicate statistically significant differences $(P<0.05)$

control level in mice with LE plus melatonin treatment (LE + MT group) (13.4 \pm 0.48$)$ (Fig. 2a; $P<0.05)$. On day 7.5 , the beneficial effects of melatonin on implantation sites were observed in the MT and LE + MT groups compared to the control and LE groups $(12.0 \pm 0.37$ and $11.4 \pm 0.40$ vs. $11.7 \pm 1.48$ and $10.0 \pm 0.58$, respectively. Fig. $2 \mathrm{a} ; \mathrm{P}<0.05)$. Representative images of the implantation sites in the uterus of mice with different treatments are shown in Fig. 2 b.

\section{Experiment III}

1. Effects of melatonin on serum $\mathrm{E}_{2}$ and $\mathrm{P}_{4}$ levels on Days 4 and 4.5 of pregnancy
There was no significant difference in serum $\mathrm{P}_{4}$ content between control and melatonin treated mice on Days 4 and 4.5 of pregnancy (Fig. 3a). In contrast, melatonin treatment significantly increased serum $\mathrm{E}_{2}$ content on Day $4(16.7 \pm 1.48$ vs. $12.2 \pm 1.49 \mathrm{pg} / \mathrm{ml})$ and on Day $4.5(59.7 \pm 8.59$ vs. $33.6 \pm 5.34 \mathrm{pg} / \mathrm{ml})$ compared to the controls, respectively (Fig. 3b).

\section{Effects of melatonin on protein levels of MT1, MT2, p53 and LIF in uteri of mice on day 4.5}

The signal pathway analyses demonstrated that the relative protein levels of MT1 and MT2 receptors in uteri of mice that received melatonin treatment were significantly upregulated compared to the controls, and the magnitude of increase in MT2 expression was significantly higher
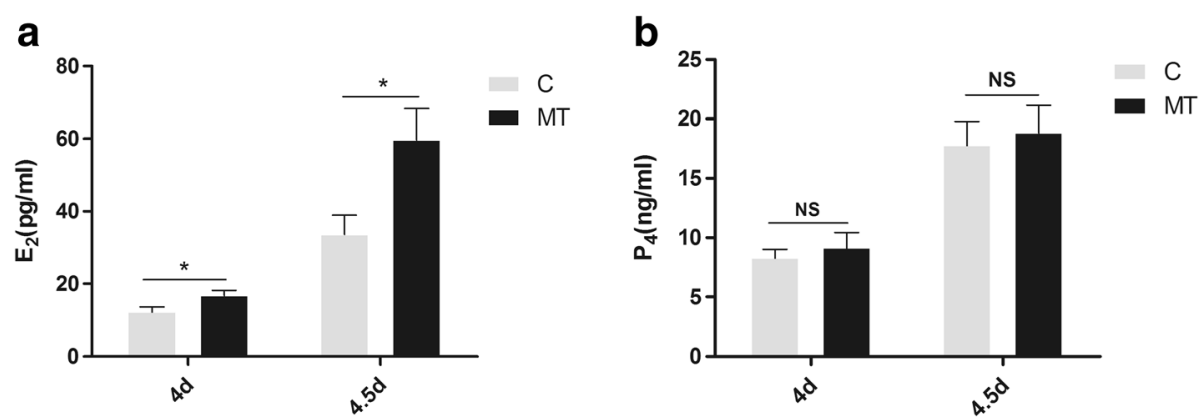

Fig. 3 Serum $P_{4}$ and $E_{2}$ contents on Days 4 and 4.5 of pregnancy. The levels of $P_{4}$ and $E_{2}$ were determined. a Serum $E_{2}$ content showed significant differences on both day $4(59.68 \pm 8.59 \mathrm{pg} / \mathrm{ml}$ vs. control $16.71 \pm 1.48 \mathrm{pg} / \mathrm{ml} ; P<0.05)$ and day $4.5(33.62 \pm 5.34 \mathrm{pg} / \mathrm{ml} \mathrm{vs}$. control $12.16 \pm 1.49 \mathrm{pg} / \mathrm{ml} ; P<0.5)$. Data are expressed as the means $\pm \operatorname{SEM}(N=9)$ Different superscript letters indicate statistically significant differences $(P<0.05)$. b No significant difference was found in serum $P_{4}$ content between the control group and melatonin group on day 4 $(9.12 \pm 1.31 \mathrm{ng} / \mathrm{ml}$ vs. control $8.27 \pm 0.73 \mathrm{ng} / \mathrm{ml} ; P>0.05)$ and day $4.5(18.82 \pm 2.31 \mathrm{ng} / \mathrm{ml}$ vs. control $17.76 \pm 2.05 \mathrm{ng} / \mathrm{ml} ; P>0.05)$ 
than that of MT1 (MT1: $27.8 \pm 3.23$ vs. control $10.7 \pm 5.38 \%$ and MT2: $50.5 \pm 3.41$ vs. control $26.6 \pm 5.29 \%$; $P<0.05$; Fig. 4a). p53 expression was also significantly higher in melatonin treated mice than in controls $(38.3 \pm 3.69$ vs. $26.4 \pm 2.65 \%$; $\mathrm{P}<0.05$, Fig. $4 \mathrm{~b})$. There was no difference in the relative level of LIF between the two groups ( $26.9 \pm 6.50$ vs. $26.3 \pm 4.73 \% ; P>0.05$; Fig. $4 \mathrm{c})$.

\section{Discussion}

During pregnancy, the early loss of embryos is a primary factor that affects litter size in mammals. In the current study, we confirmed that melatonin treatment in pregnant mice significantly increased litter size. This observation was consistent with previous publications on mice and rats $[24,34]$. Rats with a melatonin deficiency caused by pinealectomy had heavier uteri, a thicker endometrium, lower glandular organ weights, higher gland cavities, more uterine epithelial cells and increased variation capacity in attaching to the placenta; melatonin treatment reversed these alterations [24, 25]. In addition, pinealectomy in mice influenced the serum progesterone and $17 \beta$-estradiol levels, the expression of the endometrial progesterone receptor and ovarian corpus luteum numbers, and melatonin supplementation effectively reversed all these changes [25]. Some reports indicated that pinealectomy resulted in keratinization, continued oestrus and ovulation obstacles in rats [38]. Rodents with pinealectomy or under continuous illumination tended to show precocious puberty, ovarian atrophy, chronic and persistent oestrus and hyperprolactinemia [39]. These observations suggest that the melatonin circadian

\section{a1}

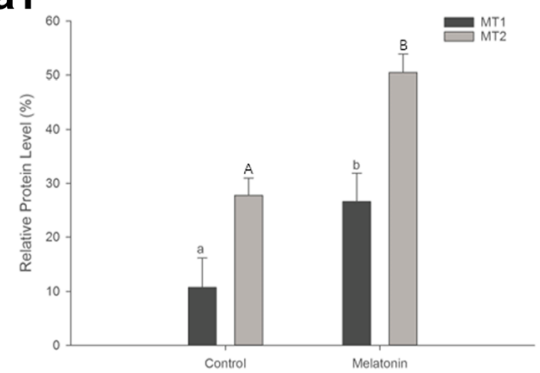

b1
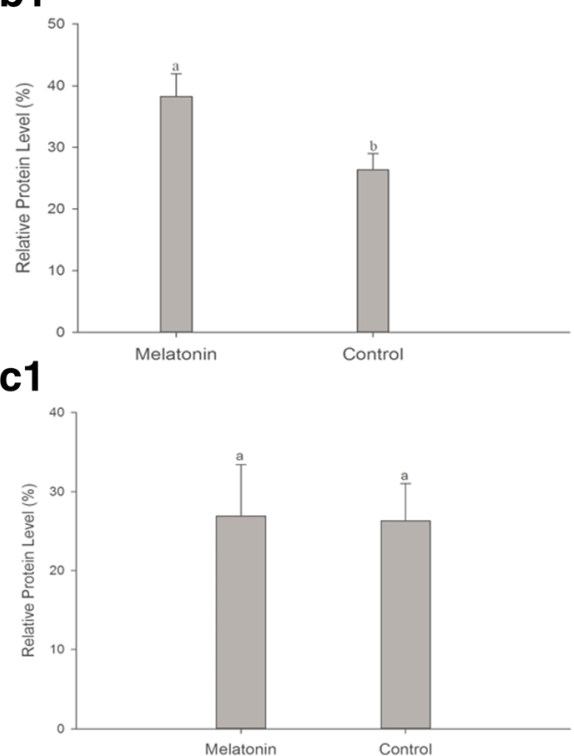

a2

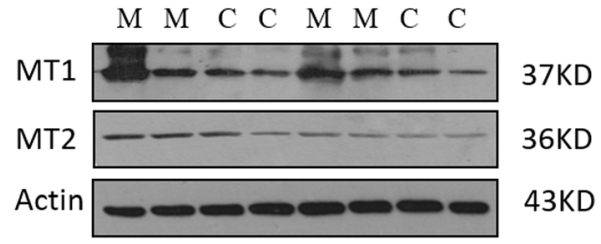

b2

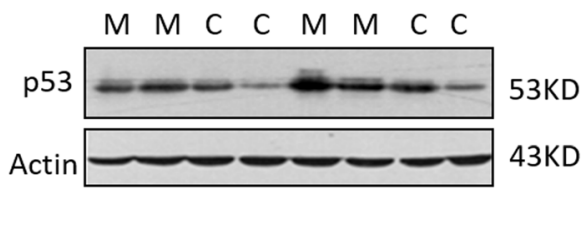

c2

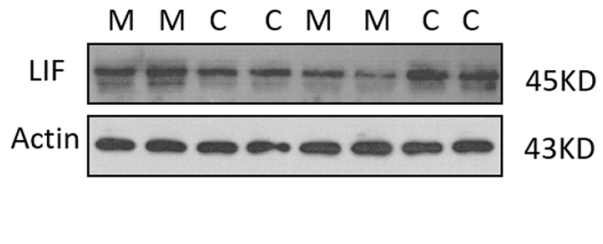

Fig. 4 Effects of melatonin on the protein expression of MT1, MT2 and p53 on Day 4.5 in uterine tissue. (a1) On Day 4.5, MT1 and MT2 receptor expression in the uterus was significantly higher in melatonin $\left(10^{-4} \mathrm{M}\right.$ )-treated samples than in control samples (MT1: $27.8 \pm 3.23 \% \mathrm{vs}$. control $10.7 \pm 5.38 \%$ and MT2: $50.5 \pm 3.41 \%$ vs. control $26.6 \pm 5.29 \% ; P<0.05$ ), and MT2 expression was higher than MT1 expression. (b1) Uterine p53 expression significantly increased in melatonin-treated group ( $38.3 \pm 3.69 \%$ vs. control $26.4 \pm 2.65 \%$; $P<0.05)$. (c1) The relative protein expression level of LIF. There was no significant difference between the melatonin and control group ( $26.9 \pm 6.50 \%$ vs. control $26.3 \pm 4.73 \% ; P>0.05)$. (a2, b2 \& c2) Western blotting results of uterine MT1, MT2, p53 and LIF protein expression. Different superscript letters indicate statistically significant differences $(P<0.05)$. Data are expressed as the means \pm SEM $(N=8)$. Different superscript letters indicate statistically significant differences $(P<0.05)$ 
rhythm is essential for regulating reproductive hormones (17ß-estradiol, progesterone) and for embryo development and implantation. In the current study, we observed, for the first time, that mice under prolonged light exposure had fewer embryo implantation sites. Prolonged light exposure decreases melatonin production in organisms [40,41]. This finding indicated that the decreased embryo implantation sites resulted from melatonin deficiency. Indeed, melatonin supplementation in drinking water $\left(10^{-4} \mathrm{M}\right)$ counteracted the negative effects of prolonged light exposure on pregnant mice and increased their embryo implantation sites back to the control levels. $\mathrm{P}_{4}$ is essential for embryo implantation and pregnancy maintenance in all mammals, and $E_{2}$ has different effects depending on the species and physiological conditions, as mentioned previously [1]. Both of these hormones are regulated by melatonin via the HPG axis. In the current study, the level of $\mathrm{P}_{4}$ in the blood wasn't changed by melatonin treatment; however, melatonin significantly increased the level of $E_{2}$. These observations were not consistent with the results obtained in rats [24] and this may be a species difference. The serum $E_{2}$ peak is essential for uterine receptivity. A high level of $E_{2}$ is beneficial for the implantation of an embryo, but the duration of uterine receptivity could become short under a high level of $\mathrm{E}_{2}[3,4]$. The current study showed that melatonin at $10^{-5}$ to $10^{-4} \mathrm{M}$ increased the number of embryo implantation sites in pregnant mice. During the time window of uterine receptivity, exogenous melatonin enhanced the level of serum $E_{2}$. Based on the results, we concluded that the increased litter size was probably achieved by the promotion of mouse embryo implantation sites induced by exogenous melatonin treatment.

Among the pregnancy outcomes, birth weight is one of the most important indexes. We observed that melatonin treatment did not affect the pups' birth weights, weaning survival rates, or weaning weights. In addition, the average litter weight was improved in rats exposed to low-nutrient conditions with melatonin treatment [42]. The authors concluded that melatonin influenced the diastolic function of the blood vessels to enhance the efficiency of the placental nutrition supply [42]. At the same time, the microenvironment of the uterus was improved by melatonin treatment, which promoted the expression of peroxidase and antioxidant enzymes such as Mn-SOD in the placenta [42]. In another study, mice treated with melatonin via injection exhibited increased gene expression of $\operatorname{ErbB} 1$, PRA, p53 and MT2 [34]. At least it can be concluded that the administration of melatonin does not cause negative effects on offspring.
The activities of melatonin might be mediated by its receptors, since melatonin receptors are present in the ovary and uterine mesangial matrix of rats and mice $[25$, 41, 42]. MT1 and MT2 melatonin receptors were differentially expressed in pregnant and non-pregnant human uterine tissue, and affected the circadian rhythms of both uterine contraction and childbirth [20,43]. To explore the signal pathway of melatonin in regulating embryo implantation, the protein levels of MT1, MT2 p53 and LIF in uterine tissue were evaluated, and MT1 and MT2 were already expressed in the uteri of mice at day 4.5 of pregnancy. In addition, exogenous melatonin administration significantly promoted the expression of MT1 and MT2. Melatonin had more profound effects on MT2 than on MT1, indicating that MT2 may be the dominant receptor to mediate melatonin's effect on reproduction. Melatonin was shown to upregulate the expression of p53 and p21 by affecting p38 activity and increasing the phosphorylation level of p53 [32, 33, 44, 45]. A specific inhibitor of p38 MAPK (PD98059) could block the effect of melatonin on p53 [45]. The cell selective gene silencing of melatonin receptors or the use of chemical inhibitors such as luzindole could suppress the readjustment of p53 [44]. Thus, MT1 and MT2 activation by melatonin regulates the expression of $\mathrm{p} 38$, resulting in the accumulation of p53 and its phosphorylation [33]. The results showed that melatonin upregulated the expression of MT1 and MT2 with the enhanced expression of p53 in the mouse uterus. p53 has been identified as a crucial factor for implantation and is the upstream regulator of the expression of LIF [9]. The results indicate that p53 may be a downstream element of MT1/2 activation and melatonin could regulate p53 and then upregulate LIF expression to improve embryo implantation. We also recognize the limitations of our study. Currently, we cannot distinguish which melatonin receptors, MT1, MT2 or both, are required for the signal transduction pathway. MT1 and MT2 or both knockout transgenic animal models will be needed for further studies.

\section{Conclusion}

In conclusion, light pollution jeopardized reproductive outcome, which was indicated by a significantly decreased number of embryo implantation sites in the uteri of mice that were maintained under long photoperiodic exposure. This observation has significant clinical implications for pregnant night shift workers such as nurses and other women of reproductive age who work at night. We also observed that melatonin treatment in pregnant mice had a beneficial effect, including an increase in litter size and litter weight. This was achieved by an increase in the number of 
embryo implantation sites at the early gestation. A possible molecular mechanism is that melatonin administration increases the $E_{2}$ levels during pregnancy and upregulates p53 expression, which is mediated by the activation of MT1/2 in the uteri of mice. All of the changes improve the microenvironment of the uterus and, thus, the outcomes of pregnancy. If the results of the animal study can be translated to humans, pregnant night shift workers may benefit from melatonin supplementation. However, more animal and clinical studies are required.

\section{Abbreviations}

$\mathrm{E}_{2}$ : 17ß-estradiol; MT: Melatonin; MT1: Melatonin receptor type 1; MT2: Melatonin receptor type 2; $\mathrm{P}_{4}$ : Progesterone

\section{Acknowledgements}

The authors thank the staff of The Beijing Northern Biotechnology Research Institute. for sample collection and serum progesterone and oestrogen assays.

\section{Funding}

This research was supported by the National Natural Science Foundation of China (31372306), National Program on Key Basic Research Project (973 Program) (2014CD138505)

\section{Availability of data and materials}

Not applicable.

\section{Authors' contribution}

LZ and GL conceived this study. LZ, FW, XT and ZZ performed the research and analysed the results. $L Z$ and $Z Z$ drafted and revised the manuscript with important contributions from GL. All authors read and approved the final manuscript.

\section{Ethics approval}

All experimental protocols concerning the handling and care of mice were in accordance with the requirements of the Institutional Animal Care Committee and were approved by the Ethics Committee of the Agriculture University of China.

\section{Consent for publication}

Not applicable.

\section{Competing interests}

The authors declare that they have no competing interests.

\section{Publisher's Note}

Springer Nature remains neutral with regard to jurisdictional claims in published maps and institutional affiliations.

\section{Author details}

'State Key Laboratory of Animal Nutrition, Key Laboratory of Animal Genetics and Breeding of the Ministry of Agriculture, National Engineering Laboratory for Animal Breeding, College of Animal Science and Technology, China Agricultural University, Beijing 100193, China. ${ }^{2}$ Present Address: Department of Animal Sciences, Purdue University, West Lafayette, IN 47907, USA.

Received: 9 June 2017 Accepted: 19 September 2017 Published online: 02 October 2017

\section{References}

1. Wang HB, Dey SK. Roadmap to embryo implantation: Clues from mouse models. Nat Rev Genet. 2006;7:185-99.

2. Cha J, Sun X, Dey SK. Mechanisms of implantation: Strategies for successful pregnancy. Nat Med. 2012;18:1754-67.
3. Groothuis PG, Dassen HHNM, Romano A, Punyadeera C. Estrogen and the endometrium: Lessons learned from gene expression profiling in rodents and human. Hum Reprod Update. 2007;13:405-17.

4. Ma WG, Song H, Das SK, Paria BC, Dey SK. Estrogen is a critical determinant that specifies the duration of the window of uterine receptivity for implantation. P Natl Acad Sci Usa. 2003;100:2963-8.

5. Gidleybaird AA, Oneill C, Sinosich MJ, Porter RN, Pike IL, Saunders DM. Failure of implantation in human invitro fertilization and embryo transfer patients - the effects of altered progesterone estrogen ratios in humans and mice. Fertil Steril. 1986;45:69-74.

6. Tan J, Paria BC, Dey SK, Das SK. Differential uterine expression of estrogen and progesterone receptors correlates with uterine preparation for implantation and decidualization in the mouse. Endocrinology. 1999; 140:5310-21.

7. Lydon JP, Demayo FJ, Funk CR, Mani SK, Hughes AR, Montgomery CA, et al. Mice lacking progesterone-receptor exhibit pleiotropic reproductive abnormalities. Genes Dev. 1995:9:2266-78,

8. Conneely OM, Mulac-Jericevic B, Lydon JP, De Mayo FJ. Reproductive functions of the progesterone receptor isoforms: Lessons from knock-out mice. Mol Cell Endocrinol. 2001;179:97-103.

9. Hu W, Feng Z, Teresky AK, Levine AJ. P53 regulates maternal reproduction through LIF. Nature. 2007:450:721-8.

10. Stewart CL, Kaspar P, Brunet L, Bhatt H, Gadi I, Kontgen F, et al. Blastocyst implantation depends on maternal expression of leukemia inhibitory factor. Nature. 1992:359:76-9.

11. Stewart CL. The role of leukemia inhibitory factor (LIF) and other cytokines in regulating implantation in mammals. Ann N Y Acad Sci. 1994;734:157-65.

12. Levine AJ, Tomasini R, McKeon FD, Mak TW, Melino G. The p53 family: Guardians of maternal reproduction. Nat Rev Mol Cell Biol. 2011;12:259-65.

13. Feng Z, Zhang C, Kang HJ, Sun Y, Wang H, Naqvi A, et al. Regulation of female reproduction by $\mathrm{p} 53$ and its family members. FASEB J. 2011;25:2245-55.

14. Carrillo-Vico A, Guerrero JM, Lardone PJ, Reiter RJ. A review of the multiple actions of melatonin on the immune system. Endocrine. 2005;27:189-200.

15. Ekmekcioglu C. Melatonin receptors in humans: Biological role and clinical relevance. Biomed Pharmacother. 2006;60:97-108.

16. Claustrat B, Brun J, Chazot G. The basic physiology and pathophysiology of melatonin. Sleep Med Rev. 2005;9:11-24.

17. Reiter RJ, Tan D, Manchester LC, Paredes SD, Mayo JC, Sainz RM. Melatonin and reproduction revisited. Biol Reprod. 2009;81:445-56.

18. Rivest RW, Jaconi M, Gruaz N, Sizonenko PC, Aubert ML. Short-term and long-term effects of melatonin on gnrh-stimulated gonadotropin-secretion in pituitaries of sexually maturing rats. Neuroendocrinology. 1987;46:379-86.

19. Reiter RJ, Mayo JC, Tan DX, Sainz RM, Alatorre-Jimenez M, Qin L. Melatonin as an antioxidant: Under promises but over delivers. J Pineal Res. 2016;61:253-78.

20. Morgan MA, Silavin SL, Wentworth RA, Figueroa JP, Honnebier B, Fishburne $\mathrm{Jl}$, et al. Different patterns of myometrial activity and 24-h rhythms in myometrial contractility in the gravid baboon during the 2nd-half of pregnancy. Biol Reprod. 1992;46:1158-64.

21. Yie SM, Niles LP, Younglai EV. Melatonin receptors on human granulosa-cell membranes. J Clin Endocr Metab. 1995:80:1747-9.

22. Brzezinski A, Fibich T, Cohen M, Schenker JG, Laufer N. Effects of melatonin on progesterone production by human granulosa lutein cells in culture. Fertil Steril. 1992;58:526-9.

23. Woo M, Tai CJ, Kang SK, Nathwani PS, Pang SF, Leung P. Direct action of melatonin in human granulosa-luteal cells. J Clin Endocr Metab. 2001;86:4789-97.

24. Dair EL, Simoes RS, Simoes MJ, Gomes Romeu LR, Oliveira-Filho RM, Haidar $M A$, et al. Effects of melatonin on the endometrial morphology and embryo implantation in rats. Fertil Steril. 2008;893:1299-305.

25. Teixeira AA, SMJT C. Evaluation of the implantation in pinealectomized and/ or submitted to the constant illumination rats. Int J Morphol. 2004;3:189-94.

26. Soares JM, Simoes MJ, Oshima C, Mora OA, de Lima GR, Baracat EC. Pinealectomy changes rat ovarian interstitial cell morphology and decreases progesterone receptor expression. Gynecol Endocrinol. 2003;17:115-23.

27. Abd-Allah A, El-Sayed E, Abdel-Wahab MH, Hamada F. Effect of melatonin on estrogen and progesterone receptors in relation to uterine contraction in rats. Pharmacol Res. 2003;47:349-54.

28. Chuffa LGA, Seiva FRF, Favaro WJ, Teixeira GR, Amorim JPA, Mendes LO, et al. Melatonin reduces $L H, 17$ beta-estradiol and induces differential regulation of sex steroid receptors in reproductive tissues during rat ovulation. Reprod Biol Endocrin. 2011;9 
29. Okatani Y, Morioka N, Hayashi K. Changes in nocturnal pineal melatonin synthesis during the perimenopausal period: Relation to estrogen levels in female rats. J Pineal Res. 1999;27:65-72.

30. Wang F, Tian X, Zhang L, Gao C, He C, Fu Y, et al. Beneficial effects of melatonin on in vitro bovine embryonic development are mediated by melatonin receptor 1. J Pineal Res. 2014;56:333-42.

31. Asgari Z, Ghasemian F, Ramezani M, Bahadori MH. The effect of melatonin on the developmental potential and implantation rate of mouse embryos. Cell J. 2012;14:203-8.

32. Mediavilla MD, Cos S, Sanchez-Barcelo EJ. Melatonin increases p53 and p21 WAF1 expression in MCF-7 human breast cancer cells in vitro. Life Sci. 1999;65:415-20.

33. Santoro R, Mori F, Marani M, Grasso G, Cambria AM, Blandino G, et al Blockage of melatonin receptors impairs p53-mediated prevention of DNA damage accumulation. Carcinogenesis. 2013;34:1051-61.

34. He C, Wang J, Li Y, Zhu K, Xu Z, Song Y, et al. Melatonin-related genes expressed in the mouse uterus during early gestation promote embryo implantation. J Pineal Res. 2015;58:300-9.

35. Reiter RJ, Tamura H, Tan DX, Xu XY. Melatonin and the circadian system: Contributions to successful female reproduction. Fertil Steril. 2014;102:321-8.

36. Reiter RJ, Tan DX, Korkmaz A. The circadian melatonin rhythm and its modulation: Possible impact on hypertension. J Hypertens Suppl. 2009;27:S17-20

37. Chepesiuk R. Missing the dark: Health effects of light pollution. Environ Health Perspect. 2009;117:A20-7.

38. Dardes RC, Baracat EC, Simoes MJ. Modulation of estrous cycle and LH, FSH and melatonin levels by pinealectomy and sham-pinealectomy in female rats. Prog Neuro-Psychopharmacol Biol Psychiatry. 2000;24:441-53.

39. Acunacastroviejo D, Fernandez B, Castillo JL, Delaguila CM. Similarity between the effects of suprachiasmatic nuclei lesions and of pinealectomy on gonadotropin-release in ovariectomized, sulpiride-treated and melatonin-replaced rats. Experientia. 1993;49:797-801.

40. Dumont M, Lanctot V, Cadieux-Viau R, Paquet J. Melatonin production and light exposure of rotating night workers. Chronobiol Int. 2012;29:203-10.

41. Wehr TA. The durations of human melatonin secretion and sleep respond to changes in daylength (photoperiod). J Clin Endocrinol Metab. 1991;73: 1276-80.

42. Richter HG, Hansell JA, Raut S, Giussani DA. Melatonin improves placental efficiency and birth weight and increases the placental expression of antioxidant enzymes in undernourished pregnancy. J Pineal Res. 2009;46:357-64.

43. Tamura H, Takasaki A, Taketani T, Tanabe M, Lee L, Tamura I, et al. Melatonin and female reproduction. J Obstet Gynaecol Res. 2014;40:1-11.

44. Proietti S, Cucina A, Dobrowolny G, D'Anselmi F, Dinicola S, Masiello MG, et al. Melatonin down-regulates MDM2 gene expression and enhances p53 acetylation in MCF-7 cells. J Pineal Res. 2014;57:120-9.

45. Santoro R, Marani M, Blandino G, Muti P, Strano S. Melatonin triggers p53(Ser) phosphorylation and prevents DNA damage accumulation. Oncogene. 2012;31:2931-42.

\section{Submit your next manuscript to BioMed Central and we will help you at every step:}

- We accept pre-submission inquiries

- Our selector tool helps you to find the most relevant journal

- We provide round the clock customer support

- Convenient online submission

- Thorough peer review

- Inclusion in PubMed and all major indexing services

- Maximum visibility for your research

Submit your manuscript at www.biomedcentral.com/submit

) Biomed Central 